\title{
Imitation of Climate Change Impacts on Growth and Yield of Wheat Crop in Eastern India
}

\author{
Uma Shankar Gupta, Shatruhan Jaiswal* and P.B.S. Bhadoria
}

Agricultural Engineering, Faculty of Agriculture Abhilashi University Chailchowk Chachyot, Dist. - Mandi - 175028, India

*Corresponding author

\section{Keywords}

Wheat,

Temperature, $\mathrm{CO}_{2}$ and CERES model

Article Info

Accepted:

20 January 2018

Available Online:

10 February 2018

\section{A B S T R A C T}

India is second most populous country after China which houses $15 \%$ of global population (census 2011) within 2.42\% of geographical land area of world. The ever growing population and improving economic condition pressurize to produce and supply higher quantity of food grains. However, the country's agriculture production is not increasing but somewhere stagnated, this increasing demand for food grain production. Agriculture sector therefore needs much attention to decrease this gap between increasing demand and production. Wheat, the staple cereal crop in world, is grown in 220.38 million hectare contributing $27.21 \%$ of total cereal grain production. In India, wheat is grown in an area of about 29.06 million hectares with a production of 86.87 million ton (FAO, 2011). The yield of wheat increased after sixties and early seventies bringing the green revolution in India. In recent years, production of wheat crop in response to the increasing application rates of the input resources is experiencing a declining trend. The decline in yield is mainly due to shortening of growth period, decrease in photosynthesis ability and increase in respiration demanding more irrigation water supply. Crop simulation models can provide an alternative, less time-consuming and inexpensive means of determining the optimum management option (Nitrogen and irrigation requirements) under varied soil and climatic conditions. Crop growth modeling has emerged as a powerful tool for optimizing crop yield and identifying critical factors, contributing to yield under varying climate change. In this context, dynamic mechanistic models CERES (Crop Environment Resource Synthesis)-Wheat available in Decision Support System for Agrotechnology Transfer (DSSAT) can be used for predicting growth and yield of wheat (Triticum aestivum L.) under different nitrogen and water management conditions. Our present study focuses the performance evaluation of CERES wheat model and use of the model for analysis of climate change impact on wheat yield. Keeping these in view the present study was formulated with the objectives of Calibration and validation of CERES-wheat model.

\section{Introduction}

The probable reasons for stagnation production are decline soil fertility and climate change. Global warming and associated climate change will affect agricultural crop yield because of alterations in temperature and rainfall cycle and through changes in soil quality, pests and diseases. The decline in yield is mainly due to shortening of growth 
period, decrease in photosynthesis ability and increase in respiration demanding more irrigation water supply. Climate change because of increasing concentration of atmosphere $\mathrm{CO}_{2}$ may bring benefits to some parts of the world, especially in developed countries, but it is a threat to food security in the developing countries. This is due to the generally predicted deleterious impacts on agriculture, particulars in tropical and subtropical countries (Parry et al., 2004). Crop simulation models can provide an alternative, less time-consuming and inexpensive means of determining the optimum management option (Nitrogen and irrigation requirements) under varied soil and climatic conditions. Crop growth modeling has emerged as a powerful tool for optimizing crop yield and identifying critical factors, contributing to yield under varying climate change. In this context, dynamic mechanistic models CERES (Crop Environment Resource Synthesis)Wheat available in Decision Support System for Agrotechnology Transfer (DSSAT) can be used for predicting growth and yield of wheat (Triticum aestivum L.) under different nitrogen and water management conditions. DSSAT is one of the potential modeling tools that can simulate appropriately the growth, development and yield of crops, using soil, weather and management as input data to the model. Suitably validated crop simulation models could be used to test many such combinations in a brief time and such simulations can adequately describe relative trends in yields caused by environmental variation (Penning de Vries et al., 1989). To assess the vulnerability of agriculture to climate change, it is necessary to consider the role of adaptation, as appropriate adaptation can greatly reduce the magnitude of impacts of climate change. Analysis of climate change impacts on wheat production and evaluation and adaptation is lacking in eastern India. Xiao et al., (2005) conducted a field experiment on rain-fed spring wheat (Triticum aestivum) at the Haiyuan Experimental Station $\left(36^{\circ} 34^{\prime} \mathrm{N}, 105^{\circ} 39^{\prime} \mathrm{E}\right)$, in China, during 20012003. According to the experimental design, the $\mathrm{CO}_{2}$ concentration increased by 90 $\mu \mathrm{mol} / \mathrm{mol}$ (from 360 to $450 \mu \mathrm{mol} / \mathrm{mol}$ ), while the mean daily temperature, during the whole growth stage, increased $0.8{ }^{\circ} \mathrm{C}$ (from 14.3 to $15.1{ }^{\circ} \mathrm{C}$ ) and $1.8{ }^{\circ} \mathrm{C}$ (from 14.3 to $16.1{ }^{\circ} \mathrm{C}$ ). The results showed that the combination of a $450 \mu \mathrm{mol} / \mathrm{mol} \mathrm{CO}_{2}$ concentration and a $0.8{ }^{\circ} \mathrm{C}$ temperature increase stimulated rain-fed spring wheat yield by $\sim 5.3 \%$. The combination of a $450 \mu \mathrm{mol} / \mathrm{mol} \mathrm{CO}_{2}$ concentration and a $1.8^{\circ} \mathrm{C}$ temperature increase, however, reduced wheat yield by $5.7 \%$. This combined effect on wheat yield presents the result of global climate changes over the next 30 years in semiarid regions of China. As an agronomic practice, supplemental irrigation of $30 \mathrm{~mm}$ may compensate for any loss of yield caused by climatic changes in the future. Furthermore, 60 and $90 \mathrm{~mm}$ supplemental irrigation improved wheat yield 3.8 and $10.1 \%$, respectively.

Ziska (2008) examined two contrasting spring wheat cultivars, Marquis and Oxen, over a 3year period under field conditions at two different planting densities. Marquis was introduced into North America in 1903, and is taller, with greater tiller plasticity (i.e. greater variation in tiller production), smaller seed and lower harvest index relative to modern wheat cultivars. Oxen, a modern cultivar released in 1996, produces fewer tillers, and has larger seed with a higher harvest index relative to Marquis. Under ambient $\mathrm{CO}_{2}$ conditions, Oxen produced more seed than Marquis for all 3 years. However, at a $\mathrm{CO}_{2}$ concentration $250 \mu \mathrm{mol} / \mathrm{mol}$ above ambient (a concentration anticipated in the next 50-100 years), no differences were observed in seed yield between the two cultivars, and vegetative above ground biomass (e.g. tillers) was significantly higher for Marquis relative to Oxen in 2006 and 2007. Significant $\mathrm{CO}_{2}$ by 
cultivar interaction was observed as a result of greater tiller production and an increased percentage of tillers bearing panicles for the Marquis relative to the Oxen cultivar at elevated carbon dioxide. This greater increase in tiller bearing panicles also resulted in a significant increase in harvest index for the Marquis cultivar as $\mathrm{CO}_{2}$ increased. While preliminary, these results intimate that newer cultivars are not intrinsically more $\mathrm{CO}_{2}$ responsive; rather, that yield sensitivity may be dependent on the availability of reproductive sinks to assimilate additional carbon. Erda et al., (2005) evaluated the climate change impacts on crop yield and quality with $\mathrm{CO}_{2}$ fertilization in China using PRECIS model. Their results showed that depending on the level of future emission, the average annual temperature expected increase by the end of $21^{\text {st }}$ century may be between $3^{\circ} \mathrm{C}$ to $4^{\circ} \mathrm{C}$. Also the modeling results elaborated that the climate change without carbon dioxide fertilization may reduce the rice, maize and wheat yields by up to $37 \%$ in the next $20-80$ years. Palosuo et al., (2011) used eight different crop growth models (APES, CROPSYST, DSSAT, DAISY, FASSET, HERMES, STICS and WOFOST) for winter wheat crop in 49 growing seasons at eight different sites of Europe to study how different process-based crop model perform at the field scale when provided with a limited set of information for model calibration and simulation. In their study, they concluded that the wide range of grain yield estimates provided by the models for all sites and years reflects substantial uncertainties in model estimates achieved with only minimum calibration. Mean predictions from the eight models, on the other hand, were in good agreement with measured data. Mutlu Ozdoğan (2011) investigated the impacts of elevated atmospheric $\mathrm{CO}_{2}$ concentrations and associated changes in climate on winter wheat yields in northwestern Turkey. They suggested prioritization of adaptation strategies in the region, including development of local cultivars of drought and heat-resistant crop varieties, earlier planting to avoid heat stress during summer, development and adoption of slower-maturing varieties to increase the grain filling period, and further investments to boost agricultural productivity.

\section{Materials and Methods}

\section{Study site}

The present study has been carried out in the research farm of Agricultural and Food Engineering Department, Indian Institute of Technology Kharagpur, Kharagpur $\left(22^{\circ} 19^{\prime} \mathrm{N}\right.$ latitude and $87^{\circ} 19^{\prime} \mathrm{E}$ longitude) India. The climate of Kharagpur is classified as sub humid, sub-tropical with hot and humid in summer (April and May), rainy during June to September, moderately hot and dry in autumn (October and November), cool and dry in winter (December and January) and moderate spring in February and March. The daily mean temperature of the study area ranges from a minimum of $12{ }^{\circ} \mathrm{C}$ in January to a maximum of $37{ }^{\circ} \mathrm{C}$ in April with average annual rainfall of $1400 \mathrm{~mm}$. The variation in average daily maximum and minimum temperatures, solar radiation and rainfall for the study area during 1971 - 2012 is shown in Figure 1.

\section{CERES-Wheat model}

CERES-Wheat, growth and yield simulation model of wheat crop that have been incorporated in DSSAT (Hoogenboom et al., 1994). The CERES model simulates crop growth, development and yield taking into account the effects of weather, genetics, soil (water, carbon and nitrogen), planting, and irrigation and nitrogen fertilizer management. It includes XBuild used to create and modifies experiment files, weatherman for weather data, Gbuild for graphing output, ATCreat for observed data and SBuild for soil database. 
The CERES-Wheat model simulates phenological development of the crop; growth of grains, leaves, stems, and roots; biomass accumulation based on light interception and environmental stresses; soil water balance; and soil $\mathrm{N}$ transformations and uptake by the crop.

\section{Input parameters}

Input requirements for CERES-Wheat include site characteristics weather and soil conditions, plant characteristics, and crop management (Hunt et al., 2001).

Site

Latitude, longitude, elevation, slope, water table depth.

\section{Weather}

Daily solar radiation, maximum and minimum air temperature, and precipitation. Solar radiation can be approximated from other observations, such as the number of sunshine hours, which is sometimes more readily available.

\section{Soil}

\section{Physical properties}

Depths of layers, percentages of sand, silt, and clay, and bulk density at various depths, moisture content at lower limit (LL, 15 bars), drained upper limit (DUL, 1/3 bar), and at saturation (SAT) for various depths (if they are not available, they could be estimated from percentages of sand, silt, and clay and bulk density).

\section{Chemical properties}

$\mathrm{pH}$, organic carbon, total nitrogen, Cation Exchange Capacity.

\section{Crop management}

Plant population, planting depth, and date of planting, irrigation and fertilizer scheduling, tillage operations and residue management etc.

\section{Genetic coefficients}

Coefficients related to photoperiod sensitivity, duration of grain filling, conversion of mass to grain number, grain filling rates, vernalization requirements, stem size, and cold hardiness.

\section{Growth and yield simulation}

Crop growth is simulated by employing a carbon balance approach in a source-sink system (Ritchie et al., 1998).

Daily crop growth rate is calculated as:

$$
\text { PCARB }=\frac{\text { RUE } \times \text { PAR }}{\text { PLTPOP }}\left(1-\mathrm{e}^{(-\mathrm{k} \times \text { LAI })}\right) \times \mathrm{CO}_{2}
$$

Where,

PCARB $=$ Potential growth rate, $\mathrm{g} /$ plant

RUE = Radiation use efficiency, (gm dry matter/MJ PAR)

PAR = Photosynthetically active radiation $\left(\mathrm{MJ} / \mathrm{m}^{2}\right)$

PLTPOP = Plant population, plants $/ \mathrm{m}^{2}$

$\mathrm{K}=$ Light extinction factor

$\mathrm{LAI}=$ Green leaf area index

$\mathrm{CO}_{2}=$ Carbon dioxide concentration (ppm)

The stages of development are determined by the accumulation of thermal time (Growing degree days). Thermal time is computed with the following equation: 


$$
\begin{gathered}
\mathrm{GD}_{\text {day }}=\mathrm{T}_{\text {avg }}-\mathrm{T}_{\mathrm{GDdays} b a s e} \\
\mathrm{CGD}_{\text {day }}=\mathrm{CGD}_{\text {day }-1}+\mathrm{GD}_{\text {day }}
\end{gathered}
$$

Where,

GD day $\left({ }^{\circ} \mathrm{C}\right.$-days $)$ is today's thermal time.

CGD day $\left({ }^{\circ} \mathrm{C}\right.$-days) is today's accumulated thermal time since planting.

TGD day base and T cutoff are crop input parameters that define the range of temperatures for viable development.

Tmin $\left({ }^{\circ} \mathrm{C}\right)$ is the daily minimum air temperature.

Tmax $\left({ }^{\circ} \mathrm{C}\right)$ is the daily maximum air temperature.

\section{Model calibration and validation}

Model calibration or parameterization is the adjustment of parameters so that simulated values compare well with observed values. Statistical methods are selected to compare the results from simulation and observation during model validation. Model validation is presented by the Root Mean Square Error (RMSE), Root Mean Square Error normalized (RMSEn) and D-index.

$\operatorname{RMSE}=\left\{\sum_{\mathrm{i}=1}^{\mathrm{n}}\left(\mathrm{S}_{\mathrm{i}}-\mathrm{Ob}_{\mathrm{i}}\right)^{2} / \mathrm{n}\right\}^{0.5}$

$\operatorname{RMSE}_{\mathrm{n}}=100\left\{\sum_{\mathrm{i}=1}^{\mathrm{n}}\left(\mathrm{S}_{\mathrm{i}}-0 \mathrm{~b}_{\mathrm{i}}\right)^{2} / \mathrm{n}\right\}^{0.5} / \mathrm{Ob} \mathrm{avg}_{\mathrm{g}}$
$\mathrm{D}=1-\frac{\sum_{\mathrm{i}=1}^{\mathrm{n}}\left(\mathrm{S}_{\mathrm{i}}-\mathrm{Ob}_{\mathrm{i}}\right)^{2}}{\sum_{\mathrm{i}=1}^{\mathrm{n}}\left(\mid \mathrm{S}_{\mathrm{i}}-\overline{\mathrm{Ob}} \text { avg }|+| \mathrm{Ob}_{\mathrm{i}}-\overline{\mathrm{Ob}} \text { avg } \mid\right)^{2}}$

Where $S_{i}$ and $O b_{i}$ are the model simulated and experimental measured points, respectively. $\overline{O b_{\text {avg }}}$ is average of observed values from one treatment or multiple treatments and $\mathrm{n}$ is the observed data points from number of treatments.

\section{Results and Discussion}

Calibration and validation of CERESwheat

\section{Calibration}

Model calibration is the adjustment of model parameter so that simulated output compare well with observed ones.

Genetic coefficients of the model CERESWheat were calibrated for the cultivar 'Sonalika' using experimental data on crop phenology, leaf area index (LAI), biomass and yield of the crop for the year 2010-11 at Kharagpur, eastern India. Sowing time and fertilizer dose of the wheat crop for the location is given in Table 1. A basal dose of $50 \%$ of total Nitrogen and $100 \%$ of total recommended phosphorous $\left(50 \mathrm{~kg} / \mathrm{ha}\right.$ of $\left.\mathrm{P}_{2} \mathrm{O}_{5}\right)$ and potassium $\left(60 \mathrm{~kg} / \mathrm{ha}\right.$ of $\left.\mathrm{K}_{2} \mathrm{O}\right)$ were applied at sowing.

The remaining $\mathrm{N}$ was applied in two equal splits at 25 and 45 days after sowing. Calibrated genotype coefficients for wheat cultivar Sonalika are given in Table 2.

The variation between the observed and simulated values for the anthesis and maturity days was 0 and 3 days, respectively 2010-11. Table 3 Simulated and observed crop parameters of wheat for the year 2010-2011 (calibration) (Fig. 2-4). 


\section{Calibration and validation of CERES-Wheat}

\begin{tabular}{|l|c|c|c|}
\hline \multicolumn{1}{|c|}{ Crop parameter } & Simulated & Observed & Variation \\
\hline Anthesis day(DAS) & 65 & 65 & 0 days \\
\hline Maturity day (DAS) & 102 & 105 & -3 days \\
\hline Product weight (kg dm/ha) & 3971 & 4075 & $-3 \%$ \\
\hline Product number (no/m²) & 13692 & 14090 & $-3 \%$ \\
\hline Product harvest index & 0.37 & 0.35 & $6 \%$ \\
\hline Maximum leaf area index & 3.8 & 3.2 & $19 \%$ \\
\hline Canopy (tops) weight (kg dm/ha) & 10694 & 11659 & $-8 \%$ \\
\hline Vegetative weight (kg dm/ha) & 6723 & 7584 & $-11 \%$ \\
\hline Above-ground N (kg/ha) & 120.0 & 124.4 & $-4 \%$ \\
\hline Product N(kg/ha) & 97.7 & 91.4 & $7 \%$ \\
\hline
\end{tabular}

Table.1 Simulated and observed crop parameters of wheat for the year 2011-2012 (validation)

\begin{tabular}{|l|c|c|c|}
\hline \multicolumn{1}{|c|}{ Crop parameter } & Simulated & Observed & Variation \\
\hline Anthesis day (DAS) & 67 & 65 & 3 days \\
\hline Maturity day (DAS) & 103 & 105 & -2 days \\
\hline Product weight (kg dm/ha) & 3853 & 3627 & $6 \%$ \\
\hline Product number (no/m²) & 13287 & 13794 & $-4 \%$ \\
\hline Product harvest index & 0.40 & 0.32 & $25 \%$ \\
\hline Maximum leaf area index & 3.4 & 2.8 & $21 \%$ \\
\hline Canopy (tops) weight (kg dm/ha) & 9625 & 11227 & $-14 \%$ \\
\hline Vegetative weight (kg dm/ha) & 5772 & 7600 & $-24 \%$ \\
\hline Above-ground N (kg/ha) & 103.6 & 110.3 & $-6 \%$ \\
\hline Product N (kg/ha) & 82.4 & 75.9 & $9 \%$ \\
\hline
\end{tabular}


Table.2 Effect of different sowing dates and nitrogen fertilizer application rate on wheat grain yield $(\mathrm{kg} / \mathrm{ha})$

\begin{tabular}{|c|c|c|c|c|c|c|}
\hline \multirow{2}{*}{$\begin{array}{c}\text { Sowing } \\
\text { dates }\end{array}$} & \multicolumn{5}{|c|}{$\mathbf{N}$ fertilizer (kg/ha) } & \multirow[t]{2}{*}{ Mean } \\
\hline & 0 & 60 & 120 & 180 & 240 & \\
\hline 15-Oct & 2189 & 2567 & 2832 & 2987 & 3069 & 2729 \\
\hline 30-Oct & 2486 & 2883 & 3099 & 3236 & 3329 & 3006 \\
\hline 15-Nov & 2849 & 3373 & 3649 & 3787 & 3863 & 3504 \\
\hline 30-Nov & 3036 & 3588 & 3886 & 4042 & 4132 & 3737 \\
\hline 15-Dec & 2996 & 3575 & 3873 & 4028 & 4117 & 3718 \\
\hline 30-Dec & 2791 & 3391 & 3717 & 3893 & 3989 & 3556 \\
\hline 15-Jan & 2223 & 2803 & 3128 & 3284 & 3369 & 2962 \\
\hline Mean & 2653 & 3168 & 3455 & 3608 & 3696 & \\
\hline
\end{tabular}

Table.3 Effect of different sowing dates of nitrogen fertilizer application rate on wheat tops weight $(\mathrm{kg} / \mathrm{ha})$

\begin{tabular}{|c|c|c|c|c|c|c|c|}
\hline $\begin{array}{c}\text { Sowing } \\
\text { dates }\end{array}$ & \multicolumn{6}{|c|}{ N fertilizer levels (kg/ha) } & Mean \\
\hline 15-Oct & 0 & 60 & 120 & 180 & 240 & \\
\hline 30-Oct & 70935 & 7902 & 8585 & 8963 & 9159 & 8249 \\
\hline 15-Nov & 7405 & 9875 & 9448 & 9759 & 9959 & 9028 \\
\hline 30-Nov & 7514 & 9862 & 10638 & 10940 & 11083 & 9962 \\
\hline 15-Dec & 7452 & 9489 & 10381 & 10723 & 10888 & 9787 \\
\hline 30-Dec & 6512 & 8319 & 9123 & 9486 & 9668 & 8622 \\
\hline 15-Jan & 5325 & 6761 & 7468 & 7779 & 7936 & 7054 \\
\hline Mean & 6849 & 8707 & 9501 & 9843 & 10016 & \\
\hline
\end{tabular}

Table.4 Effect of different sowing dates and nitrogen fertilizer application rate on wheat water use efficiency $(\mathrm{kg} / \mathrm{ha}-\mathrm{cm})$ of wheat crop

\begin{tabular}{|c|c|c|c|c|c|c|}
\hline $\begin{array}{c}\text { Sowing } \\
\text { dates }\end{array}$ & \multicolumn{5}{|c|}{ N fertilizer levels (kg/ha) } & Mean \\
\hline 15-Oct & 0 & 60 & 120 & 180 & 240 \\
\hline 30-Oct & 92 & 105 & 113 & 118 & 121 & 110 \\
\hline 15-Nov & 103 & 107 & 114 & 118 & 121 & 111 \\
\hline 30-Nov & 102 & 117 & 123 & 127 & 130 & 120 \\
\hline 15-Dec & 95 & 109 & 116 & 128 & 132 & 121 \\
\hline 30-Dec & 87 & 101 & 109 & 114 & 116 & 105 \\
\hline 15-Jan & 68 & 83 & 91 & 95 & 97 & 86 \\
\hline Mean & 92 & 105 & 113 & 117 & 120 & \\
\hline
\end{tabular}




\section{CERES-Wheat model}

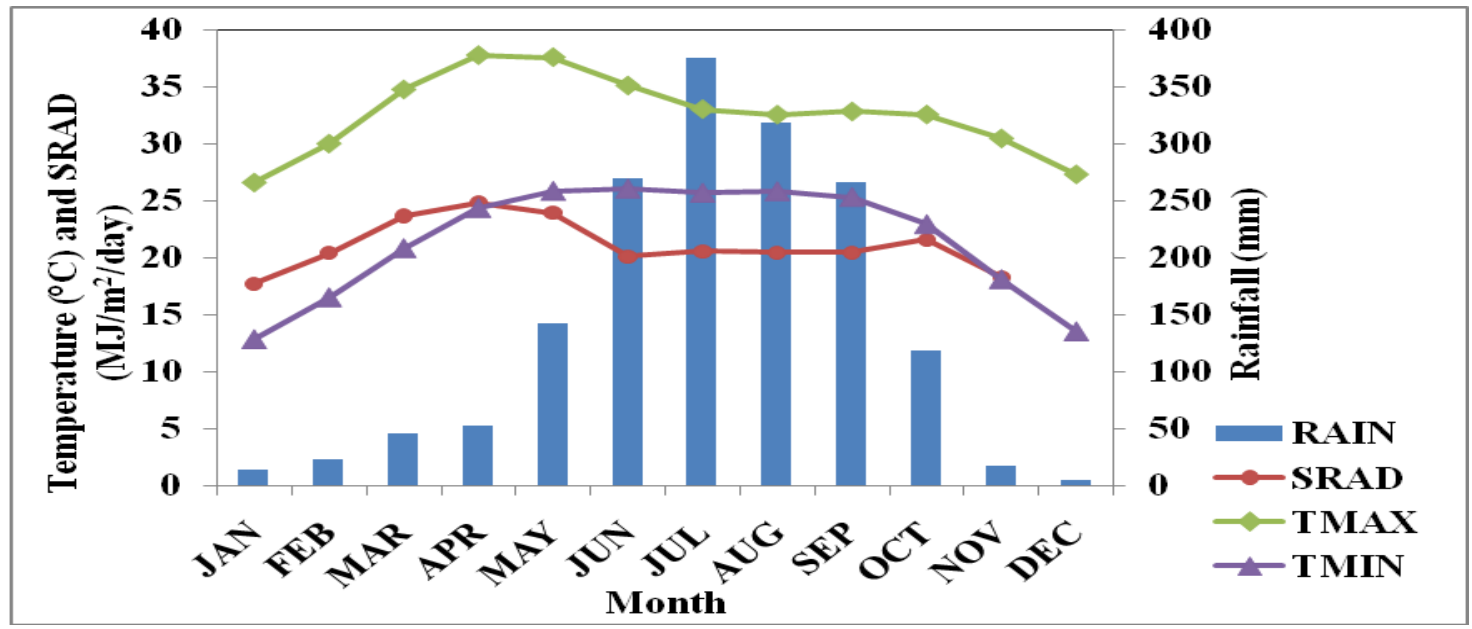

Fig.1 Observed (OBS) and simulated (SIM) time series leaf area index and leaf weight in days after sowing of wheat crop during calibration period (2010-2011)

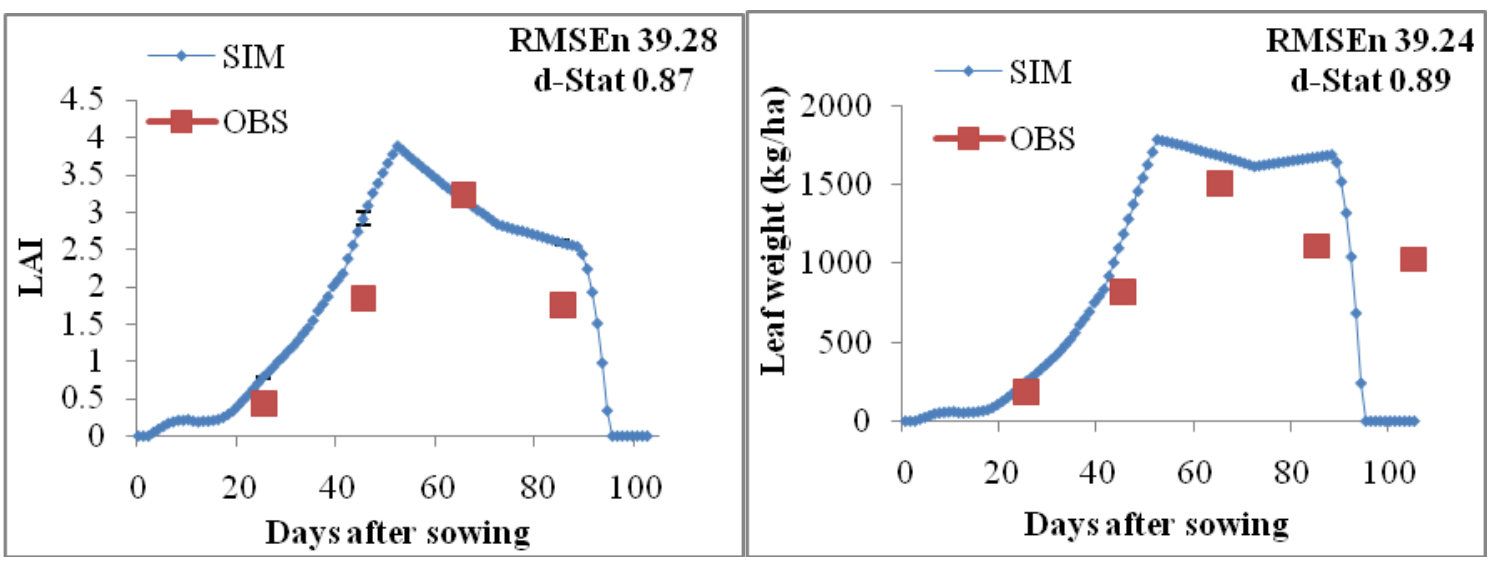

Fig.2 Observed (OBS) and simulated (SIM) time series stem weight and tops weight in days after sowing of wheat crop during calibration period (2010-2011)

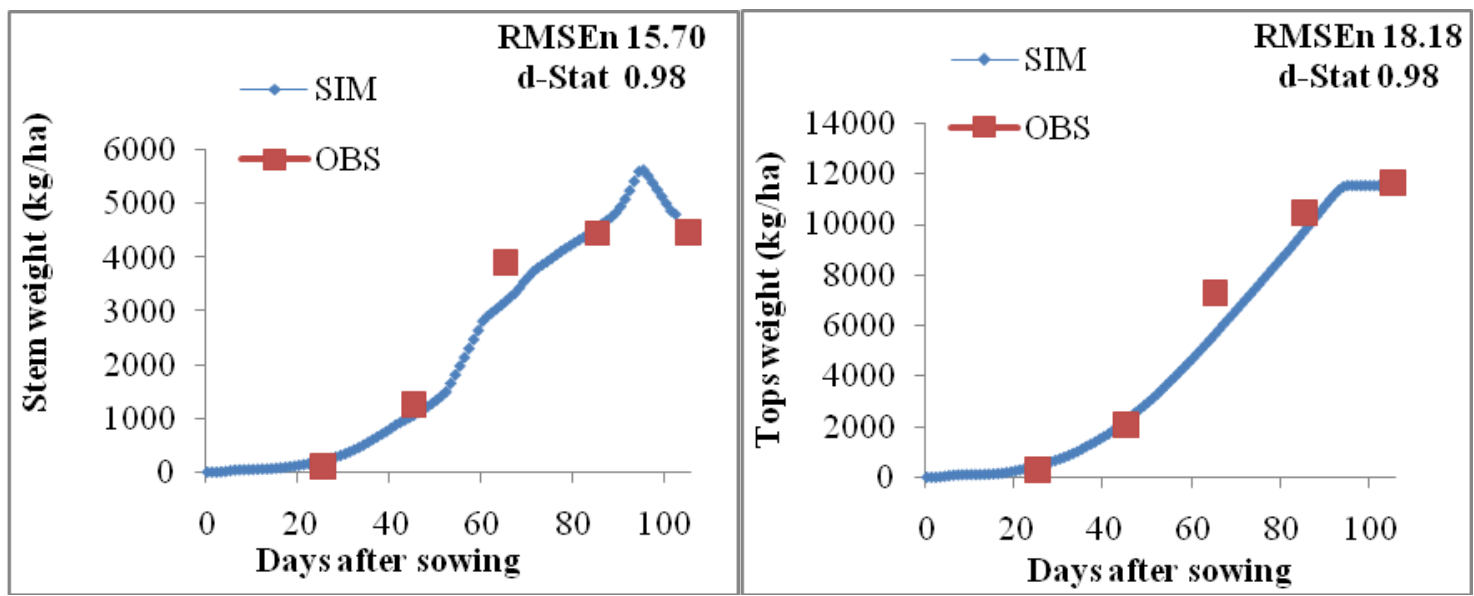


Fig.3 Observed (OBS) and simulated (SIM) time series leaf area index and leaf weight in days after sowing of wheat crop during validation period (2011-2012)

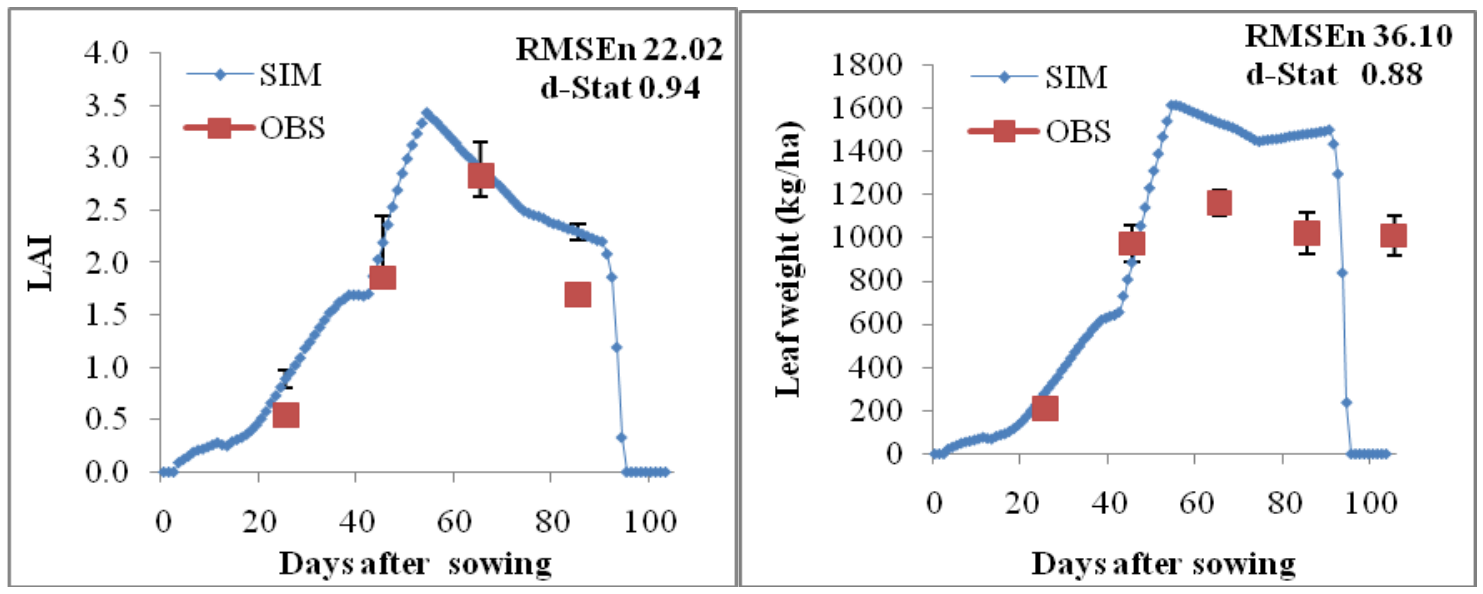

Fig.4 Observed (OBS) and simulated (SIM) series time stem weight and tops weight in days after sowing of wheat crop during validation period (2011-2012)

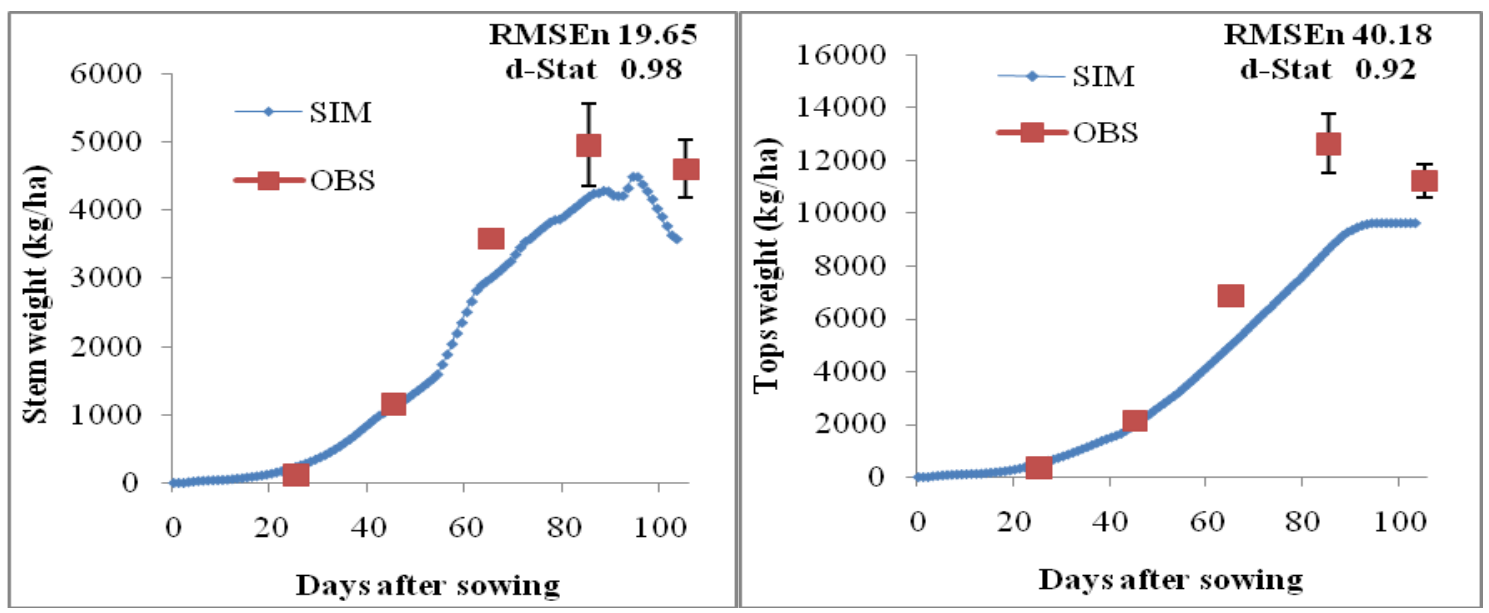

Fig.5a Simulated grain yields in past years (1975-2011) for wheat crop

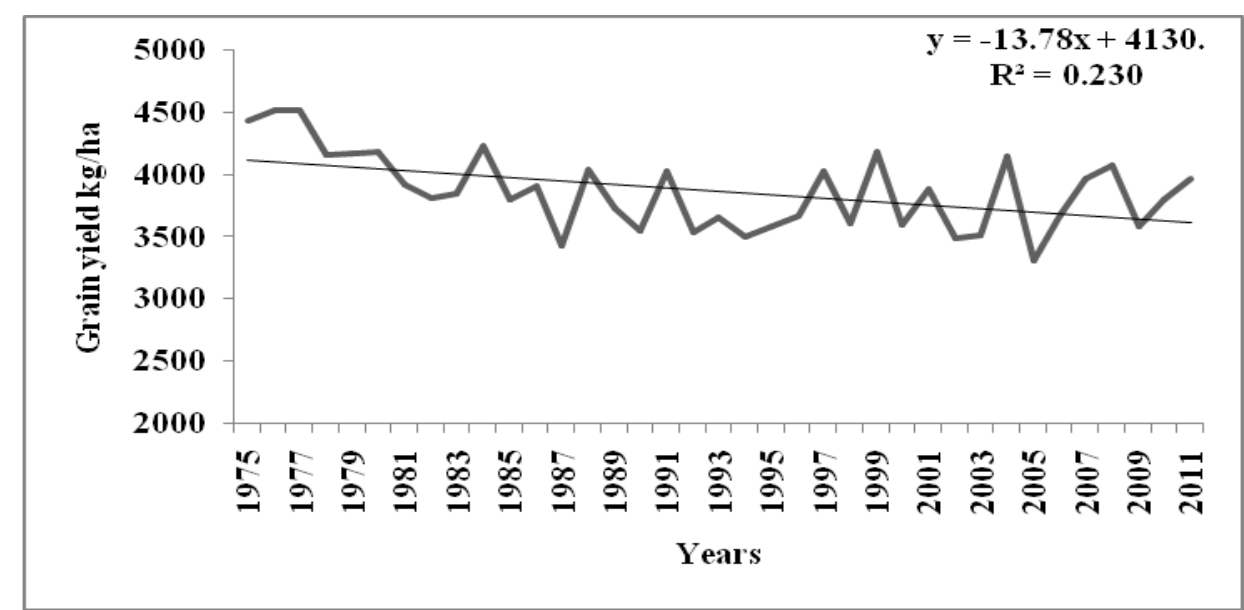


Fig.5b Average daily temperature of past years at Medinipur during 1975-2012

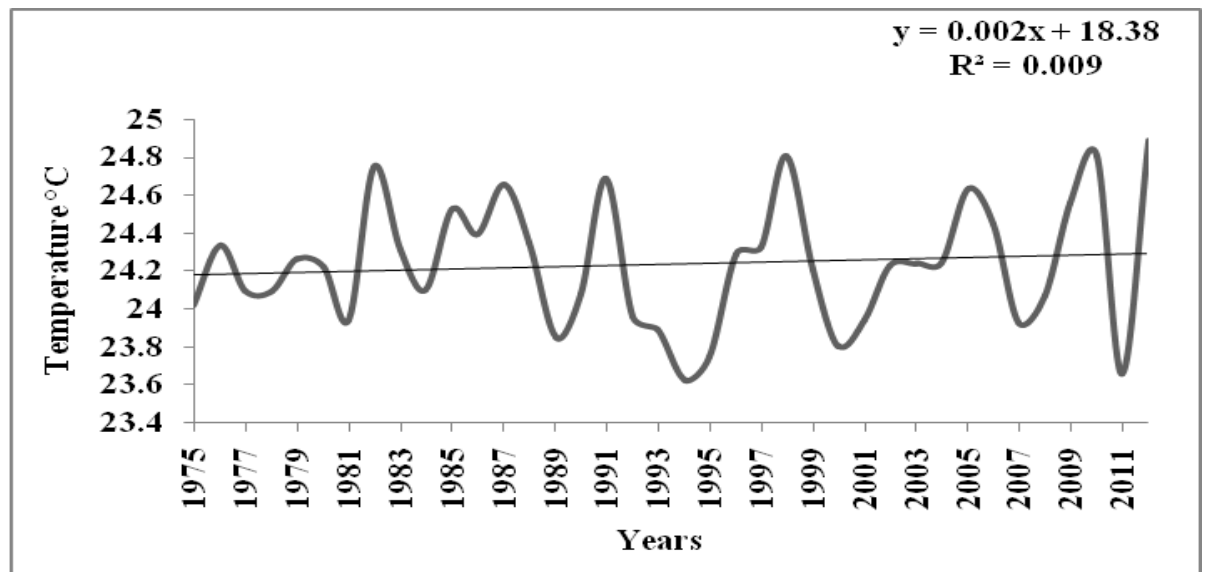

Fig.6 Change in wheat grain yield (\%) under different sowing dates and $\mathrm{N}$ fertilizer application rate as compared to the reference sowing date (30 November) and $\mathrm{N}$ fertilizer rate $(120 \mathrm{~kg} / \mathrm{ha})$

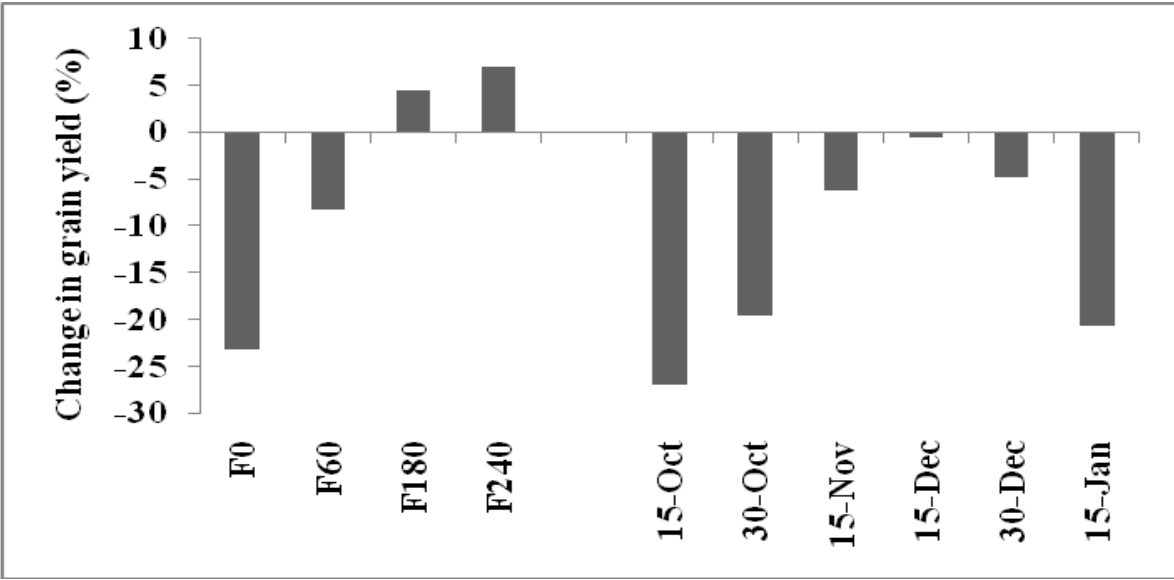

Fig.7 Effect of different sowing date on appearance of anthesis and maturity in days after sowing of wheat crop

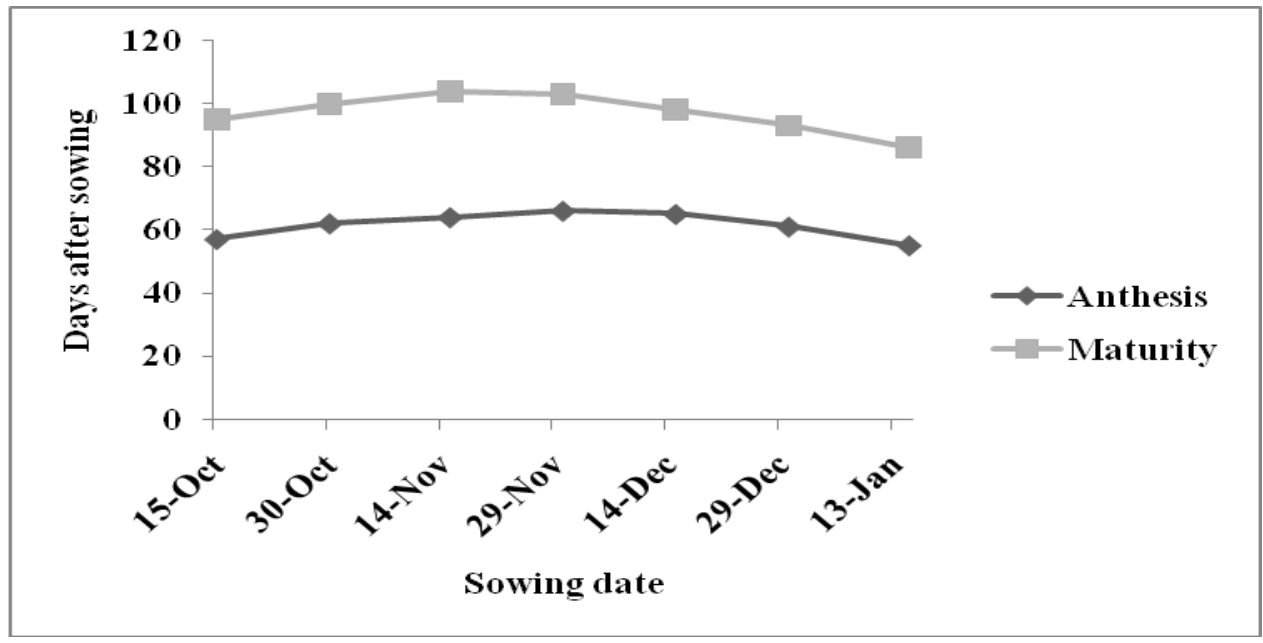




\section{Simulation of climate change impacts}

The model was applied to simulate the grain yield of wheat crop, using the historical weather data (Figure 5). The simulated grain yield over past years is decreasing trend with progress of year. The influence of different sowing dates (15 October, 30 October, 15 November, 30 November, 15 December, 30 December and 15 January) and $\mathrm{N}$ fertilizer doses $(0,60,120,180$ and $240 \mathrm{~kg} / \mathrm{ha})$ was simulated on yield of wheat crop (Table 4). The minimum grain yield of $2729 \mathrm{~kg} / \mathrm{ha}$ was simulated on 15 October sowing and maximum grain yield of $3737 \mathrm{~kg} / \mathrm{ha}$ on 30 November sowing. Among the different sowing dates, sowing on 30 November was taken as reference date since maximum yield was simulated on this date. Percentage change in the yield for the dates earlier to 30 November i.e. 15 November, 30 October and 15 November were $-6,-20$ and -27 , respectively. Similarly the percentage change in simulated grain yield for the sowing later to 30 November i.e. 15 December, 30 December and 15 January were $-1,-5$ and -21 , respectively, as shown in Figure 6. Increase N fertilizer level up to 120 and $180 \mathrm{~kg} / \mathrm{ha}$ simulated on yield improvement 30 and $36 \%$ as compared to control (no $\mathrm{N}$ application rate). Further $\mathrm{N}$ application did not simulated any significant yield improvement. The tops weight and water use efficiency were found maximum sowing on 30 November. Appearance of anthesis and maturity were 66 and 103 days after sowing for 30 November sowing date. Sowing earlier or later to 30 November reduced the maturity duration 8 and 17 days.

The present atmospheric concentration of $\mathrm{CO}_{2}$ is about $390 \mathrm{ppm}$ by volume, which is expected in the range of 535 to $983 \mathrm{ppm}$ by 2100 , about 41 to 158 percent higher than current levels. The present study has been carried out in the research farm of
Agricultural and Food Engineering Department, Indian Institute of Technology Kharagpur, Kharagpur $\left(22^{\circ} 19^{\prime} \mathrm{N}\right.$ latitude and $87^{\circ} 19^{\prime} \mathrm{E}$ longitude) India. The daily mean temperature of the study area ranges from a minimum of $12{ }^{\circ} \mathrm{C}$ in January to a maximum of $37^{\circ} \mathrm{C}$ in April with average annual rainfall of $1400 \mathrm{~mm}$. The CERES-Wheat model was used in evaluation of management options to assist decision making procedure in agricultural production system in general and climate change scenarios in particular. The CERES-Wheat model was calibrated and validated for the cultivar 'Sonalika' using experimental data on crop phenology, leaf area index (LAI), biomass and yield of the crop for the year 2010-11 and 2011-12, respectively. The CERES-wheat model was used for simulation of different adaptation management includes effect of change in planting date, variation in nitrogen application rate for minimizing the adverse impact of climate change on wheat yield. There was a good agreement between observed and simulated time series leaf area index, leaf weight, stem weight and tops weight of wheat crop with d-Stat value $0.87,0.89,0.98$ and 0.98 , respectively during calibration period (2010-2011).

Similarly for validation period (2011-2012), the d-stat value between the observed and simulated time series leaf area index, leaf weight, stem weight and tops weight of wheat crop were $0.94,0.88,0.98$ and 0.92, respectively. The variation between the observed and simulated value for grain yield was $6 \%$ and for tops weight was $14 \%$ during the validation period. The following conclusions are summarized.

The wheat sowing period around 30 November was simulated to be the best for increased production under the current and future climate scenario at Kharagpur, eastern India. 
A marginal increase in yield was simulated by shifting the sowing time from 30 Nov to 15 December under future climate scenarios.

The $\mathrm{N}$ fertilizer application rate in the range 120 to $180 \mathrm{~kg} / \mathrm{ha}$ was recommended for the yield maximization.

\section{References}

Anwar, M. R., McNeil, D., Hossain, H. and Nelson, R. (2007). Climate change impact on rainfed wheat in southeastern Australia. Field Crops Research, 104: 139-147.

Arora, V.K., Singh H. and Singh B. (2007). Analyzing wheat productivity responses to climatic, irrigation and fertilizernitrogen regimes in a semi-arid subtropical environment using the CERESWheat model. Agricultural Water Management, 94: 22-30.

Erda, L., Wei, X., Hui, J., Yinlong, X., Yue, L., Liping, B. and Liyong, X. (2005). Climate change impacts on crop yield and quality with $\mathrm{CO}_{2}$ fertilization in China. Philosophical Transactions of the Royal Society, 360: 2149-2154.

FAO, (2011). Food and Agriculture Organization of the United Nations. http://faostat.fao.org/site/567/DesktopD efault.aspx?PageID=567\#ancor.

Hundal, S. S. and Kaur P. (2007). Climatic variability and its impact on cereal productivity in Indian Punjab. Current Science Association, 92: 506-512.

IPCC. (2007). Summary for Policymakers of Climate Change: The Physical Science Basis. Contribution of Working Group I to the Fourth Assessment Report of the Intergovernmental Panel on Climate Change. Cambridge University Press, Cambridge.

Ma, H.L., Zhu, J.G., Liu, G., Xie, Z.B., Wang, Y.L., Yang, L.X. and Zeng, Q. (2007). Availability of soil nitrogen and phosphorus in a typical rice-wheat rotation system under elevated atmospheric $\left[\mathrm{CO}_{2}\right]$. Field Crops Research, 100: 44-51.

Nagarajan, S., Jagadish, S., Hariprasad, A. K., Anand, A., Pal, M. and Agarwal, P. K. (2010). Local climate affects growth, yield and grain quality of aromatic and non-aromatic rice in northwestern India. Agriculture, Ecosystems and Environment, 138: 274-281.

Palosuo, T., Kersebaum, K. C., Angulo, C., Hlavinka, P., Moriondo, M., Olesen, J. E., Patil, R. H., Ruget, F., Rumbaur, C., Takac, J., Trnka, M., Bindi, M., Caldag, B., Ewert, F., Ferrise, R., Mirschel, W., Saylan, L., Siska, B. and Rotter, R. (2011). Simulation of winter wheat yield and its variability in different climates of Europe: A comparison of eight crop growth models. European Journal of Agronomy, 35: 103-114.

Parry, M.L., Rosenzweig, C., Iglesias, A., Livermore, M. and Fisher, G. (2004). Assessing the effects of climate change on global food production under socioeconomic scenarios. Global Environ, Change, 14: 53-67.

Penning de Vries, F., Jansen, D., ten Berge, H. and Bakema, A. (1989). Simulation of ecophysiological processes of growth in several annual Crops. Pudoc, Wageningen, the Netherlands.

Reidsma, P., Ewert, F., Lansink, A. and Leemans, R. (2010). Adaptation to climate change and climate variability in European agriculture: The importance of farm level responses. European Journal of Agronomy, 32: 91102.

Singh, A. K., Tripathy, R. and Chopra, U. K. (2008). Evaluation of CERES-Wheat and CropSyst models for waternitrogen interactions in wheat crop. Agricultural Water Management, 96(7): 776-786. 
Srivastava, A., Naresh, K. S. and Aggarwal, P.K. (2010). Assessment on vulnerability of sorghum to climate change in India. Agriculture, Ecosystems and Environment, 138: 160-169.

Timsina, J. and Humphreys, E. (2006). Performance of CERES-Rice and CERES-Wheat models in rice-wheat systems. Agricultural Systems, 90: 531.

Xiao, G., Zhang, Q., Li, Y., Wang, R., Yao, Y., Zhao, H. and Bai, H. (2010). Impact of temperature increase on the yield of winter wheat at low and high altitudes in semiarid northwestern China. Agricultural Water Management, 97: 1360-1364.

You, L., Rosegrant, M. W., Wood, S. and Sun, D. (2009). Impact of growing season temperature on wheat productivity in China. Agricultural and Forest Meteorology, 149: 1009-1014.

Ziska, L.H. (2008). Three-year field evaluation of early and late 20th century spring wheat cultivars to projected increases in atmospheric carbon dioxide. Field Crops Research, 108: 5459.

\section{How to cite this article:}

Uma Shankar Gupta, Shatruhan Jaiswal and Bhadoria, P.B.S. 2018. Imitation of Climate Change Impacts on Growth and Yield of Wheat Crop in Eastern India. Int.J.Curr.Microbiol.App.Sci. 7(02): 2223-2235. doi: https://doi.org/10.20546/ijcmas.2018.702.268 